essays

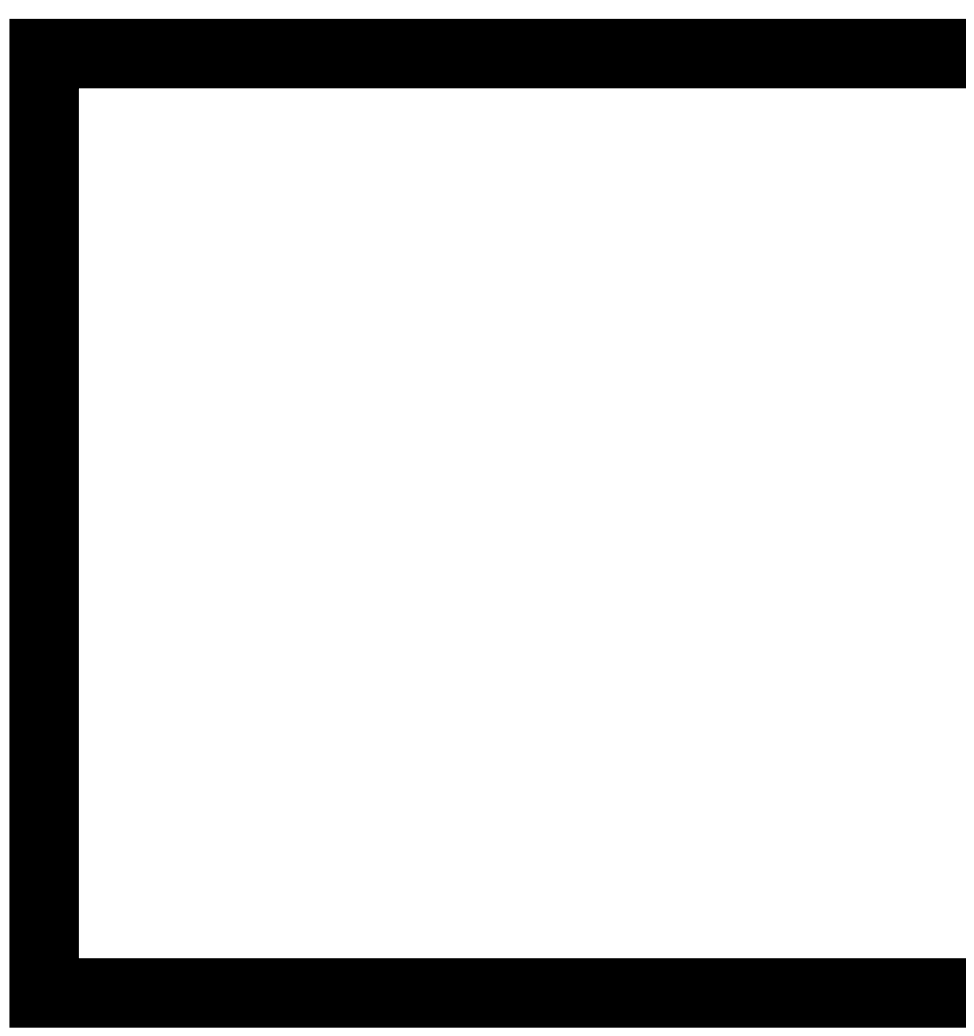




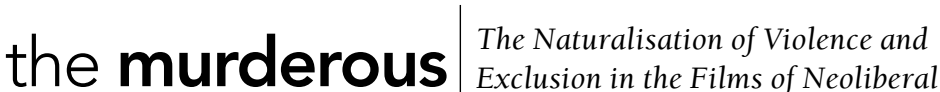 state Australia \\ JON STRATTON}

Jindabyne was released in 2006 to much praise. Based on a Raymond Carver short story, discussion of the film focused on the characters and the consequences of the four fishermen failing to immediately report that they had found a dead body floating in the river. There was hardly any mention that the film harbours a serial killer. In a rare exception Avril Curruthers in In Film Australia wrote that, 'Although there is a murder in [the film], and a serial killer, these are simply the stone to the ripple effect that is the main concern of the film'. ${ }^{1}$ Here, the serial killer and, indeed, the murder are identified only so that they can be dismissed. Yet there is no serial killer in the Carver story. The presence of a serial killer is not necessary to the film's moral issues and psychological action. However, the predatory surveillance of Gregory, the serial killer, frames the film. He is the first person we see, and the last, sitting in his van on top of a rocky outcrop monitoring the road, and the vast, flat plain across which it snakes, with his binoculars. Narratively, for the film's viewers, Gregory's presence through the film—he is embedded in the community as the town's electrician-appears to be simply taken for granted.

Gregory is not the only serial killer in recent Australian films. There is the much betterknown Mick Taylor in the slasher genre film, Wolf Creek, released a year earlier in 2005, to unexpected popularity. Taylor patrols the outback of northern Western Australia. He has a shed full of the cars and other mementos of the tourists that he has murdered. In the film's narrative, of the three backpackers he brutalises only Ben, the Sydneysider, survives. In both these films the police are ineffectual and barely present (not at all in Taylor's outback) and the serial killers remain at large at the film's conclusion. In both, audiences can assume that Gregory and Mick Taylor will continue their murderous ways. 
They are not the only people to get away with murder in recent Australian films. In The Proposition the murderous psychotic is only finally stopped by the moral revulsion of his brother who, killing him at the film's conclusion, is seemingly justified in the lawless land of 1880s outback Queensland and having, in a twisted way, fulfilled his agreement with Captain Stanley, the policeman, will go free. In Suburban Mayhem, also released in 2006, Katrina goads her boyfriend Rusty into killing her father and, when she thinks he doesn't have the balls to do it, uses her sexual wiles on her intellectually challenged brother Danny to persuade him to do the deed. As things fall out, Rusty commits the murder and Danny is convicted. Nothing can be traced back to Katrina. At the end of this black, and bleak, comedy, it is clear that Katrina has not used the money from the sale of her father's house to fund an appeal against her brother's conviction for murder. Rather, she and Rusty are living quite blissfully in a cottage by the sea. In both these films murder has its reward.

There is one more film I want to add to this list, even though it does not contain a murder. Kenny, also released in 2006, is a mockumentary about a sanitary worker. The titular Kenny is portrayed as endearingly passive, accepting good-heartedly the impositions of everybody from his selfish ex-wife and his thoughtless, overbearing father to the badly behaved, mostly middle-class, customers who use the portakabin toilets that Kenny's firm supplies for large gatherings. Until, that is, almost at the end of the film, when an obviously middle-class young man uncaringly parks his car and goes to see his girlfriend who works in a local shop, blocking in Kenny's tanker full of sewerage. After a number of attempts to get the man to move his car Kenny finally loses his patience and, in an echo of a well-known urban myth, starts to fill the car with sewerage. This is a comedy and a mockumentary; indeed, as I will argue, Kenny is an example of the carnivalesque, so this scene stands in for murder. Clearly the audience is expected to side with Kenny and approve of his wanton destruction of the recalcitrant owner's car. To aid this identification, the scene stops here. Kenny, we should note, remains unable to move his tanker. Clearly, this is of less importance than Kenny's self-satisfying burst of road rage.

More importantly for the argument that I am building here, Kenny at no time considers contacting the police and, since this scene is so close to the end of the film, we never get to see the consequences of Kenny's action. Indeed, as the film moves towards its conclusion we have the strong impression that there are no consequences for Kenny-legal or in terms of his job. Kenny not only gets away with a spiteful, personal act of revenge but the film asks its audience to praise him for it. Here, as in Suburban Mayhem, the personal is validated over the social and the individual action, transgressive as it might be from a social point of view, brings its reward-financial in Suburban Mayhem and cathartic retaliation in Kenny. A social morality that acknowledges the worth of a shared social order is here replaced by a personal ethics that privileges individualistic desires. 
What is going on in these films? What I want to argue is that we are at a watershed in Australian culture, that these films, and others, mark a shift in the Australian national imaginary. ${ }^{2}$ Since the Hawke-Keating years, but especially since the return of the Coalition to power under John Howard in 1996, Australia has been increasingly managed according to the ideological tenets of neoliberalism. As Dennis Woodward has explained, since the 1980s:

A particular version of economic theory - the 'Washington Consensus'-became dominant in Australia (following the rest of the Anglo-Saxon countries) and increasingly elsewhere.

This dominant economic theory is called 'neoliberal economics'. ${ }^{3}$

I am not arguing here, though, that Australia has become an incarnation of the theory of neoliberalism as expressed by the economist Friedrich Hayek, its most celebrated originator and proponent. Rather, Australia, in similar manner to many other Western countries, has adopted a mixed bag of Hayekian and other neoconservative economic practices which, together, are most easily identified as neoliberalism and this is the general term that I shall be using in this article.

The ideological precepts that underlie these economic practices are now beginning to be found naturalised and reproduced in Australian cultural products. By this I certainly do not mean that writers and filmmakers are consciously making films that are driven by neoliberal ideologies. Rather, I argue that the ideological elements of neoliberalism are becoming so naturalised in Australian society that they are now appearing in Australian cultural products as 'obvious' elements of the story line. Thus, for example, when I discuss Jindabyne, I am not arguing that Ray Lawrence made the film as a vehicle for neoliberal ideology. Indeed, it is clear from his interviews that Lawrence holds many views sympathetic to traditional left-wing values. Nevertheless, the naturalisation of a mixture of neoliberal and neoconservative assumptions in Australia has had the consequence of these being reproduced in Lawrence's, and others, films. While there are, of course, other ways of reading the films under discussion here, it is this reproduction that I am seeking to tease out in this article.

What interests me most in this article are the narratives and characterisations in the films I am discussing. It is at these sites that we can find reproduced the clearest expressions of those neoliberal ideological assumptions that are coming to dominate Australian social life. It could be argued that genre plays an important part in the reception of Australian films and, while this is true, I suggest that this is secondary to the importance of narrative and character. Thus, for example, that Suburban Mayhem is a comedy helps to make more acceptable to viewers Katrina's determination to have her father murdered, and that Kenny uses documentary techniques, in this way making Kenny more 'real', helps to disguise the 
extent to which Kenny's character can be read as the personification of neoliberalism's ideal worker.

\section{— Neoliberalism and individualism}

Neoliberalism has been conventionally understood as a political ideology founded in a capitalistic economics that places the market, and indeed the free market, as the basis for all human relations. Following the ideas of her mentor, Hayek, Margaret Thatcher, then prime minister of Great Britain, notoriously commented in a 1987 Woman's Own interview that there is no such thing as society:

and who is society? There is no such thing! There are individual men and women and there are families and no government can do anything except through people and people look to themselves first. It is our duty to look after ourselves and then also to help look after our neighbour and life is a reciprocal business and people have got the entitlements too much in mind without the obligations. ${ }^{4}$

The social implications of a political philosophy that dismisses the idea of society and valorises not only the individual but the individual whose moral outlook is founded on looking after themselves first before anybody else are immense. Henry Giroux is one cultural critic who has commented on these. He writes:

Neoliberalism has heralded a radical economic, political, and experiential shift that now largely defines the citizen as a consumer, disbands the social contract in the interests of privatized considerations, and separates capital from the context of place. Under such circumstances, neoliberalism portends the death of politics as we know it, strips the social of its democratic values, and reconstructs agency in terms that are utterly privatized and provides the conditions for an emerging form of proto-fascism that must be resisted at all costs. ${ }^{5}$

As Giroux implies, ideologically it is the idea of a social contract, as developed by such early political theorists as Thomas Hobbes, John Locke and Jean-Jacques Rousseau, that has founded the claim that society, defined here as the shared relationships between human beings, is the assumed basis of order within the modern state.

In The Political Theory of Possessive Individualism, C. B. MacPherson explained the connection in the work of Hobbes, writing in the seventeenth century, between the human being, constructed as a possessive individual, and the social contract. In Leviathan, published in 1651, Hobbes argued that in the State of Nature, where there would be no government, human beings would relentlessly fight each other, indeed murder each other, in order to gain personal power, advantage and safety. As a consequence, as Hobbes put it in a resonant 
phrase, in such circumstances people would live in 'continual fear, and danger of violent death; And the life of man, solitary, poore, nasty, brutish, and short'. ${ }^{6}$ MacPherson argued that Hobbes's State of Nature was a description of what he called a 'possessive market society', that is, we can add, a capitalistic market order 'in which men who want more may, and do, continually seek to transfer to themselves some of the powers of others, in such a way as to compel everyone to compete for more power'. ${ }^{7}$ MacPherson goes on to write that, 'all this [is] by peaceable and legal methods which do not destroy the society by open force'. This, however, is an effect of the putting in place of the social contract.

MacPherson argues that:

Once Hobbes has established that the general inclination of all men is the search for ever more power over others, he is able to show that if there were no power able to overawe them all, their lives would necessarily be miserable and insecure in the utmost degree. ${ }^{8}$

The consequence is that people come together and transfer to a new power, a sovereign, both their power and their individual rights. This transfer not only enables the competitive market to be regulated but, in the general, shared acknowledgement of the need for order, provides the basis for society. It is, ideologically, the social contract which limits the selfinterest of the possessive individual. One element of the limitation has been the establishment of a morality that places high importance on the welfare of other members of the society. The neoliberal ideological shift away from the idea of a social contract means that the selfinterest of the possessive individual is given free reign and retributive justice supplants distributive justice.

Another way of thinking about the impact of neoliberalism is by way of the idea of freedom. Freedom was a central concept in Hayek's thought. He begins The Constitution of Liberty by writing that:

We are concerned in this book with that condition of men in which coercion of some by others is reduced as much as possible in society. This state we shall describe throughout as a state of liberty or freedom. ${ }^{9}$

For Hayek this kind of freedom is established and guaranteed by the freedom of the capitalistic market. As David Harvey writes: 'The assumption that individual freedoms are guaranteed by freedom of the market and of trade is a cardinal feature of neoliberal thinking, and it has long dominated the US stance towards the rest of the world. ${ }^{10}$ Hayek's notion of freedom has much in common with what Isaiah Berlin, in his well-known essay 'Two Concepts of Liberty', describes as negative freedom: 'If I am prevented by others from doing what I could otherwise do, I am to that degree unfree, and if this area is contracted by other men beyond a certain minimum, I can be described as being coerced, or, it may be, enslaved. ${ }^{11}$ As Harvey 
indicates, for Hayek and other neoliberal and neoconservative thinkers, the limits on constraint are found in the expression of the market. What needs to be guarded with all violence is the freedom of the market itself.

Within the state, the effect of the ideology of the social contract was to establish a space where, as far as possible, violence became the prerogative of the state. Thus when Noam Chomsky writes that a 'state is a structure of violence', ${ }^{12}$ in the modern state a distinction is made between violence within the state, which is controlled by the police and regulated by law, and violence outside of the state which is practiced by the armed forces. Politically speaking, the violence that can be exerted by the police in keeping the space of the state, the space subject to the social contract, free of violence, is itself limited by the same law of the state which it is the duty of the police to uphold.

It is this law of the state which functions to articulate the space of the social contract as the site of society. Following an argument of Jacques Derrida's in 'Force of Law: The "Mystical Foundations of Authority"', Maria Giannacopoulos argues that:

Once a legal system is established through force, it eradicates all other forms of law that might judge its legitimacy. It declares certain questions, including the one about its own legality, to be non-justiciable ... The category of the non-justiciable then is the legal process through which the violence of the law is relegated to the realm of the invisible. ${ }^{13}$

The law must hide the violence of its instantiation before it can mark the limits of the order of the society born of the social contract. The ideological shift away from the social contract reveals the law as the imposition of the violence of the state. More, it withdraws the protection from violence offered in social contract ideology. As Harvey writes, quoting the economist Karl Polyani: 'But if, as is always the case, 'no society is possible in which power and compulsion are absent, nor a world in which force has no function', then the only way this liberal utopian vision could be sustained is by force, violence, and authoritarianism, or even outright fascism. ${ }^{14}$ We shall revisit these terms throughout this article.

It is at this point that, as we shall see, the police and the military become interchangeable in the neoliberal state. Or, rather, the police become redundant and are replaced by the armed forces. Thus, in 2005 we find John Howard sounding remarkably like Hobbes, telling Australians that:

The most important civil liberty I have and you have is to stay alive and be free from violence and death. I think that when people talk about civil liberties, they sometimes forget that action to protect the citizen against physical attack is a blow in favour and not a blow against civil liberties. ${ }^{15}$ 
The context for this speech was a special meeting of the Council of Australian Governments the purpose of which was to increase Australia's protection from terrorism. In Anthony Burke's words:

That meeting of state premiers and Commonwealth ministers agreed on a series of counterterrorism measures which included sweeping new legislation that overturned longstanding principles of criminal law and revived controversial laws abandoned in parliamentary negotiations in 2002, laws that would provide Australian federal security agencies with sweeping new powers of surveillance, detention, arrest and control. ${ }^{16}$

First, since 2001 the job of patrolling Australia's borders had been militarised. Suvendrini Perera succinctly describes:

the new topographies of inclusion and exclusion on land and sea created by this exercise of sovereignty [the so-called Pacific Solution] over refugee bodies: the contraction and expansion of national borders as detention camps are placed outside the space of the nation and lines are drawn in the sea to deterritorialise and excise parts of Australia from the migration zone, while yet other parts are annexed under measures such as the 'Pacific Solution', and new cartographies of surveillance constituted through extensive militarisation and policing of the oceans. ${ }^{17}$

Now, four years later, the rule of law-the state's expression of the social contract—was being set aside and protection within the Australian state was being given to quasi-military groups. These developments were legitimated by a claim to the external threat of terrorism but, as we can see, Howard's rhetoric slips easily into a Hobbesian scenario where, as Hobbes put it in Leviathan in 1651, in the State of Nature there would be a 'warre of every man, against every man' with the consequence that those highly competitive possessive individuals would require the protection of an authoritarian government's military forces.

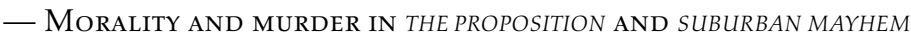

The year 2005 was also the year that the Nick Cave-scripted film, The Proposition, was released. Set in the 1880s in outback Queensland, the film is most often thought of as an Australianisation of the western. Philip French, in the English paper The Observer, for example, described it as 'stylistically influenced by the westerns of Sergio Leone, Sam Peckinpah and Monte Hellman'. ${ }^{18}$ In the film, Captain Stanley has been brought out from England by a landowner, Eden Fletcher. Stanley's remit is to stop the violence and depredation caused mostly, it would seem, by a group of Irish brothers and their associates, the Burns gang. That the film is set in a lawless, colonial Queensland helps to justify and give realism to what is, 
ideologically speaking, a Hobbesian and neoliberal world where power is an expression of wealth and violence.

Historically, that the gang is Irish and preying, apparently, on English settlers is an accurate understanding of the divide between Irish and English in nineteenth-century Australiaa divide legitimated by the English claim that the Irish were not 'white'. ${ }^{19}$ At the same time, with the neoliberal-based move against multiculturalism, the film's depiction of violent depredation by Irish against English can also be read in the present as part of the gradual breakdown of the fifty-year coalition between English and Irish which has given rise to the neologism, Anglo-Celtic. Colonial Australia, and the western genre, then, can be read in The Proposition as making neoliberal ideological assumptions more believable and, simultaneously, less obvious for viewers-in other words, more naturalised.

There is no government in the land The Proposition depicts. Stanley and his men have military titles, 'captain' and 'sergeant', yet function more like police and Stanley's wages are paid by Fletcher. Stanley and his men operate, then, not as an apparently impartial police force enforcing a law to which all are forced to subscribe but as a kind of private security force in the service of the moneyed elite. We can find a clue to what is going on here in Will Wright's The Wild West where he argues that:

Social contract theory tells a story, a theoretical story of social origin. It is a story about rational individuals leaving the State of Nature, and the cowboy myth simply retells the story for popular, cultural understanding. ${ }^{20}$

If this is the ideological force of the conventional western, we can understand that much of the violence and hopelessness of The Proposition comes from the failure to put in place a social contract, which in turn relates to the lack of government, or, thinking in today's neoliberal terms, quite simply the displacement of any possibility of a social contract by an emphasis on the individual at the expense of the law. Stanley says at the beginning of the film 'I will civilise this land', but the film is a chronicle of his failure. Giroux writes about the dismantling 'of the social contract in the interests of privatized considerations' and this reflects Stanley's situation. The Proposition can be read as a depiction of a world without a social contract and therefore without government and without a law applicable to all within this society.

At the foundation of the film is the proposition itself. Stanley has captured Charlie and Mikey Burns but the most violent brother remains at large. Stanley makes a deal with Charlie that, if he will kill his elder brother Arthur, then he and Mikey will go free. In this offer we see that Stanley himself does not function according to an established rule of law. More, and thinking in terms of the neoliberal ideology that permeates these films, his individual contract with Charlie is strongly reminiscent of the Australian Workplace Agreement individual contracts that were legislated in the Howard government's first wave of industrial relations 
reforms that came into force in January 1997. Individual contracts replace the idea of a social contract. The violence of the state is enacted in this relation. Charlie has no bargaining position. He has little choice but to accept the contract. Yet, when he finally does kill his brother, in a small triumph for individualism over family, it is not to fulfil his side of the contract for Mikey is already dead. Rather, it is an act of personal morality, an expression of Charlie's own disgust at Arthur's propensity for rape, torture and murder. At this climax of the film Stanley has let his guard down so that he and his wife can celebrate Christmas as if they were still in England, in society. Arthur, along with his offsider and Charlie, take them by surprise. Stanley is terribly assaulted and his wife is in the process of being raped. In this amoral, neoliberal world without a social contract, Stanley and his wife are saved, in spite of Stanley's inability to keep his side of the individual contract - that is, the propositionby Charlie's individual moral stand against his brother's behaviour. In The Proposition this development seems nostalgic and out of place-as, as we shall see, does the reconciliation scene between Aborigines and whites at the end of Jindabyne. We might read these scenes as sites of conflict between the ideology being reproduced in these films and the political position of the writers and/or directors. In The Proposition viewers, in the main, seem to accept the realism of Charlie's behaviour because it saves us from confronting the violent consequences of neoliberal assumptions.

Suburban Mayhem, as I have already indicated, has no such regressive moral scruples. Katrina and her boyfriend Rusty literally get away with murdering Katrina's father. The police, and the law, do have a strong and visible presence in this film. They have already arrested Danny, Katrina's brother, and secured his conviction for murder. Katrina, however, is beyond their reach. Writing about the screenplay, Andrew Urban suggests that Alice Bell 'has created a scenario that measures how far a young woman will go to impose her will on others simply for the sake of getting her way'. ${ }^{21}$ Indeed, Katrina can be read as a spunky product of postfeminism manipulating the weaknesses of the men around her in order to get her own way. Katrina, though, is much more than this. She is the validation of the possessive individual in a world where the social contract which legitimates the role of the police is breaking down. Thus, what empowers her is her sexuality and it this that she uses to get the boys to do her bidding. Sex for Katrina has no moral valence in a wider social order, it is simply a means to a personal end. It is because the position of the police is undermined that, in the narrative of the film, Katrina is able to take revenge on Detective Robert Andretti, who dobbed her into the welfare agency for neglect of her baby daughter, without there being any consequence. In this way the narrative's acceptance of Katrina's revenge parallels the revenge episode in Kenny that I have already mentioned. Revenge, it seems, is morally acceptable in the neoliberal world. Perhaps this is because revenge celebrates the perpetrator, the individual in a world without society. 
In Suburban Mayhem the family is breaking down into its component individuals. Here, we should remember Thatcher's phrase and its ordering: 'There are individual men and women, and there are families.' For the modern state the ideological claim was that the family was the foundation of society. In neoliberal political philosophy where there is no society, individuals take precedence over the family. While, in what is now an old-fashioned morality where there is respect for others, Charlie Burns's murder of his brother can be justified, it also signals the privileging of the individual over family ties. In Suburban Mayhem, Katrina's mother was a drug addict who left the family. Katrina's father, John, had to tell her to stop coming round because it upset the children. Katrina herself is a single mother in a dysfunctional relationship with her boyfriend, who is not the father of her child. Katrina's father, who attempts to force his daughter to take responsibility for her life (which, in his view, means her getting a job and taking care of her daughter), is portrayed as old-fashioned. Within the film's diegesis viewers are asked to feel little sympathy for John and, consequently, to feel little distress at his violent murder. He and his morality, which is so much that of the previous generation, before the acceptance of neoliberal cultural assumptions, is expendable in this new, selfish world.

The love of Katrina's life is her brother, and this seems to be reciprocated. Danny cuts off the head of the cashier in the convenience store he is robbing because the cashier called Katrina a slut. In this highly attenuated family, Katrina and Danny's relationship appears to set aside any concern with an incest taboo between siblings. Katrina's fantasy for the future involves her and Danny living together in a relationship which, in other circumstances, would be described as romantic. Similarly, in this transgression of modern family organisation there seems to be no emotional attachment on Katrina's side to her father. For Katrina, the possessive individual, her father is a financial resource. Thus, when Katrina thinks that an appeal against Danny's conviction will free him, her plan is to raise the money by murdering her father and selling the family home. This is the amoral Hobbesian State of Nature, or rather, it is a neoliberal world where the market is foundational, and murder is a legitimate means to fulfil personal need.

Danny, then, languishes in prison for two reasons. First, he defended his sister's reputation. Second, when Katrina explains to him how she had their father murdered so that she could appeal his conviction, Danny, traditionalist as he is revealed to be, is shocked and revolted. Danny remains in prison, Katrina lives happily ever after with Rusty in that beachhouse I have already mentioned.

\section{- Citizenship ANd exclusion}

From the point of view of the modern state, the ideology of the social contract had two important and related features. Citizenship was ascribed to those included in the social contract 
and therefore subject to the law of the state, and sovereignty was a key element in the ordering of the power of the state. Thus, the primary vector of the modern state was inclusion. It is inclusion which gives the idea of the nation its force. This is the role of inclusion, and exclusion, that Perera mentions in the quotation used earlier. As Aihwa Ong writes:

Heretofore, influential concepts of citizenship have been based on a binary opposition between the rights of citizenship rooted in a national territory and a stateless condition outside the nation-state. This politico-legal concept is based on the practical reality that only the nation-state can implement citizenship entitlements and protections claimed through recognised political membership. ${ }^{22}$

Ong goes on to assert the continuing importance of citizenship for groups such as asylum seekers and refugees but then writes that: 'Nevertheless, contemporary flows of capital and of migrants have interacted with sovereignty and rights discourses in complex ways to disentangle citizenship claims once knotted together in a single, territorialised mass. ${ }^{23}$ Ong's book focuses on the way that neoliberal states, giving primacy to the market, and global financial flows, have begun to problematise the borders of state inclusiveness. For example, she writes about the problematic status of Philippina and Indonesian maids working in large numbers in Singapore, Hong Kong and Malaysia, and also about the creation of export processing zones and regional free trade zones and their effects on sovereignty.

However, this transformation is more fundamental. In the neoliberal state, where the social contract is set aside, the preoccupation with inclusion and its limits is increasingly supplanted by a hierarchisation of state membership, of citizenship, which is founded on exclusion. Stephen R. Stoer and António M. Magalhães, writing about new forms of citizenship and education, express surprise that, 'at a time when so much emphasis is placed on inclusion, inclusive schooling and the so-called "inclusive society", social exclusion appears to be more the norm than social inclusion'. ${ }^{24}$ Assuming that inclusion remains the basis of state practice, they go on to write that, 'the definition of inclusion based on the exclusion-or attempted eradication-of difference means almost inevitably new forms of exclusion, economic, social, political and cultural'. ${ }^{25}$ We need to take a further step here and understand that the neoliberal state is not founded on inclusion but, rather, on exclusion. It is in this context, and in the ordering of the neoliberal state's heirarchisation founded on the violence inflicted on those relatively excluded, that we find the neoliberal state's preference for authoritarian government. Notoriously, Hayek himself was a supporter of General Pinochet's right-wing dictatorship in Chile, and Pinochet's attempt to impose neoliberal practices on the country. Just as notoriously, Hayek, who held a meeting of his think-tank on neoliberalism, the Mount Pelerin Society, in Chile in 1981, during the time of Pinochet's regime, was quoted in the Chilean newspaper El Mercurio as saying: 'My personal preference inclines to a liberal 
dictatorship and not to a democratic government where all liberalism is absent. ${ }^{26}$ There is a synergy, which there is no space to explore here, between the ideology of democracy and that of the social contract.

What Stoer and Magalhães are signalling in the quotation above is the neoliberal state's radical refusal to understand the possessive individual in the market situation as anything more than a human being. The effect is that state membership is consequent upon the denial of any attribute that could be understood in terms of group membership from gender, race, sexuality, disability, through to union membership and, indeed, family membership. In the neoliberal state group identification is a marker of exclusion-as in the case of those generically classified as asylum seekers and refugees. Group markers must be stripped away for state membership and individuals within the state cannot claim special concessions because of their membership of a group claiming to be suffering discrimination. The driving idea here is that identifying groups, and given group members particularised treatment depending on their circumstances within the state, would cause a malformation in the governing free market.

However, this does not mean that cultural practices within the neoliberal state are blind to these differences. They are not. In Australia, for example, whiteness becomes even more entrenched as the site of inclusion and power because of the state's determination to deny the continuing social importance of race. In the post-multiculturalism of Suburban Mayhem Katrina manipulates both the Andretti family, who are, obviously, of Italian extraction, and the girl she befriends, Lilya, who is the daughter of Polish immigrants. Katrina's Anglo, dysfunctional family is privileged over the functional non-Anglo families. Lawrence has spoken of the multiculturalism of Jindabyne-he is paraphrased as saying that he preferred the American actor, Laura Linney, for the role of Claire because 'of what he wanted: a certain foreignness which goes with the multi-culturalism [sic] of the film'27 —yet of the four men two are Anglo, one, Rocco, is of Italian extraction and one is Irish with a white American wife. Thus all, to a greater or less extent, are classified as white in early twenty-first century Australia. Indeed, in none of the films under discussion are there any main characters that Australians would describe as non-white with the exception of the Indigenous Carmel in Jindabyne. Carmel's main diegetic purpose, though, as a school teacher and girlfriend of Rocco, would seem to be to show how difficult it is for an Indigenous person to span Indigenous and white cultures. There are no 'Asians'-I am using this term here as a reflection of standard Australian usage-for example, except for the Japanese prostitutes at the beginning of The Proposition and the Thais who work in the Thai restaurant that the main characters in Jindabyne visit. Thus, in these films, 'Asians' take on well-established roles in Australian 
society: women who are sexualised and demeaned or running the town's Chinese restaurant, in Jindabyne translated into a Thai restaurant. It is in relation to Jindabyne's organisation of population that we can understand that Gregory is patrolling a white Australia.

One consequence of the now unspeakable entrenching of whiteness in state power is the naturalisation of indirect violence. Indirect violence is a function of the lack of distributive justice. Ricardo J. Gomez explains that indirect violence 'is exerted any time people are denied their basic human rights: it is a violence against the human condition. Poverty, hunger, unfair salaries, unemployment, racial and gender discrimination are all forms of indirect violence. ${ }^{28}$ Gomez justifies human rights by a metaphysical appeal to the human condition. However, politically, they are present in the modern understanding of the state by way of a claim about the responsibilities of government in relation to the social contract.

\section{- Violence and the neoliberal state}

Gomez' point, though, is not just about the lack of interest in human rights in the neoliberal state, it is about the practice of violence and its relationship to exclusion. His description of the state's practice of indirect violence relates to Ong's insight about the disentangling of aspects of citizenship:

Citizens who are deemed too complacent or lacking in neoliberal potential may be treated as less worthy subjects. Low-skill citizens and migrants become exceptions to neoliberal mechanisms and are constructed as excludable populations in transit, shuttled in and out of zones of growth. ${ }^{29}$

I think it is a misunderstanding to see what is done to low-skilled citizens and migrants as an exception to neoliberal political philosophy. To the contrary, as I have already explained, the neoliberal state is founded on a graded hierarchy of exclusion where loss of citizenship, or its lack, is the final, qualitative moment of exclusion. The free market is not, of course, free, it is a capitalistic market of employers and employed where profit is the determining feature.

With the extinction of the ideology of the social contract, violence returns in overt form as the ordering principle of the state. Class war becomes more than a metaphor. In this circumstance it is the armed forces, not the police, who keep stability in the hierarchical order. The police become gradually less relevant in a state founded on a hierarchy of exclusion and the patrolling of that exclusion. Writing about the use of the military in the relief effort following the disastrous flooding of New Orleans in the wake of Hurricane Katrina, George Caffentzis argues: 
the contemporary model for managing the working class in disasters is increasingly warfare. Workers in a disaster are increasingly being turned into rightless beings and then, when they resist, they become the 'enemy'. In this logic the refugee quickly turns into the terrorist. ${ }^{30}$

And David Theo Goldberg describes how:

In the name of securing the city, post-Katrina New Orleans was quickly turned into an armed military camp ... While critics were rightly bemoaning the dehumanizing conduct of [the Iraq] war abroad, few seemed to notice that, for domestic purposes, the United States was mimicking tactics of militarization honed in the desert war. The United States, in short, had taken to turning itself into armed and gated camps at home. ${ }^{31}$

The bulk of the area of New Orleans flooded in the disaster was working class and AfricanAmerican.

Caffentzis provides an explanation that expands Goldberg's insight:

In the past, the military in the form of the state National Guards was often dispatched to scenes of disaster. These Acts of God not only opened up 'a state of nature' but they also posed the possibility that the common bonds of mutual aid developed during the suspension of civil government would open up new modes of social coordination outside of the state and capital ... The military's role in New Orleans was not only to set the framework of a return to 'normality', it was to create a new territorial and demographic reality. ${ }^{32}$

Setting aside the invocation of Peter Kropotkin's 1902 book, Mutual Aid, a key anarchocommunist text, Caffentzis's point is that the American neoliberal government of George W. Bush opportunistically used the New Orleans disaster to legitimate the use of the armed forces to pacify Americans who, as a group, have diminished access to the market and correspondingly lesser rights as citizens-that is, who are more excluded from the state.

In Australia there has been no direct parallel with the New Orleans disaster and the concomitant legitimation of the use of the military as 'peacekeepers' on American soil. Rather, we have a creeping militarisation. We have already seen one aspect of this in new legislation opportunistically justified by the need to protect Australia from terrorism. Another example can be found in the militarisation of assistance given to remote Indigenous communities. In November 1996 John Herron, the Minister for Aboriginal and Torres Strait Islander Affairs, introduced the Army Community Assistance Program. Its purpose was to use army personnel and equipment to help train Indigenous people in trades while doing necessary construction work on the communities' infrastructure. While this seems a benign enough mission, we have to ask why it was the army that was chosen to undertake it and what the ideological effect might be of having a military presence in Australia's most disadvantaged communities. 
Certainly by mid-2006, when much horror was expressed at the levels of violence and sexual abuse in the Northern Territory Indigenous community of Wadeye, there were calls, including from Dr Paul Bauert, the president of the Northern Territory chapter of the Australian Medical Association, to have 'the military brought in as peacekeepers, similar to missions overseas'. ${ }^{3}$ Such a suggestion, coupled with the established role of the Australian military in the local region such as the Regional Assistance Mission to the Solomon Islands which was deployed in July 2003, signals the high level of exclusion of Indigenous people in the Australian neoliberal order. Bauert is not the only one to make this kind of connection. On 25 January 2007, Michael Dillon published an article titled 'National Security and the Failed State in Remote Australia'. In concluding, he writes:

notwithstanding the positive benefits to national security of the Indigenous presence in remote Australia, it is clear that offsetting these are serious and negative impacts on national security broadly defined. These impacts derive from the substantial and longstanding economic and social disadvantage faced by Indigenous citizens, the increasing threats to human security for remote citizens and the apparent incapacity of governments to both address the disadvantage and effectively ensure order and good governance. ${ }^{34}$

Dillon couches his appeal for more aid to remote Indigenous communities in the language of national security. I shall return to the situation of Indigenous exclusion when I discuss the serial killer in Jindabyne.

We have already seen how, in the wake of Hurricane Katrina, the military was brought in to pacify the African-American working class. This is an example of violent class suppression and, indeed, exclusion from the neoliberal American state. In Australia the best example of such class warfare so far is the attempt through the second half of 1997 and the first half of 1998 to break the Maritime Union of Australia (MUA). In what was often described as the 'War on the Waterfront' or the 'War on Wharfies' Patrick Stevedores, under chief executive Chris Corrigan and in collusion with the federal government, planned to displace the MUA as representative of the workers on the docks loading and unloading containers. The idea was to sack between 1400 and 2000 unionised workers and replace them with untrained and newly trained un-unionised labour. The plan came to light when it was discovered that seventy men were being sent to Dubai for three months' training in the operation of stevedoring equipment. These men were all ex-army and had been recruited through the magazine, The Army, by Mike Wells, himself a former army officer and Vietnam War veteran. Until its discovery, the plan had been that these men would form the core of the new wharf labour force. In the end the ex-army labour was not used and the MUA retained its presence on the waterfront but had to accede to significant job losses. 
The waterfront dispute illustrates well the Australian shift to a neoliberal assumption of class warfare. It is in this context that we can think about Kenny. As I explained at the beginning, Kenny is a mockumentary. It purports to show the life of a man whose job is to put in and take out portakabin toilets at large-scale events such as rock festivals, speedway meetings and the Melbourne Cup. Kenny is in the Australian tradition of films celebrating the working-class man. The most obvious comparison is with Paul Hogan's characters and, in film, his portrayal of Crocodile Dundee. Where Dundee was the self-employed bushman, always ready and able to put one over on everybody regardless of class, Kenny is the urban employee accepting of his lowly position in the employment hierarchy. A more recent comparison is with the family of working-class Aussie battlers in The Castle (1997). In this film the Kerrigans fight to keep their home, which is about to be resumed to make way for an extension of what viewers assume is Melbourne Airport. In the end the Kerrigans win on a point of constitutional law related to the Mabo decision. At one point Darryl Kerrigan remarks: 'I'm beginning to understand how the Aborigines feel.' But, of course, he can't. Rather, in a conservative and populist twist, the film appropriates the land rights decision in order to give the battling Aussie family a victory over the big end of town. ${ }^{35}$ As Christine Stapleton writes:

The defence of Darryl's case rests on invoking the Native Title Act in conjunction with his feelings for and attachment to his property and is encapsulated in the repetition of the clichés, 'its not just a house, it's a home' and 'a man's home is his castle.'

In this scenario, Aboriginal peoples' battles for land rights are muddied and the traditional relationship to the land, which underpins the land-rights movement, is reduced to a sentimentalised notion of attachment to place. ${ }^{36}$

Kenny, though, almost ten years later and much deeper into the process of neoliberal exclusionary hierarchising, is no winner, even at the expense of Aborigines.

In his private life Kenny is surrounded by selfish people. His ex-wife wants everything done to suit her. Kenny's father is thoughtless and demanding and Kenny's aspirational brother, who drives a Mercedes, is selfish and rejecting of his working-class roots-to such an extent that when Kenny organises for the three of them to spend a weekend together in the mountains because of their father's illness, his brother rings a taxi on the first evening. In the midst of these people Kenny is constantly helpful, patient and self-deprecating.

The film is organised such that when this behaviour carries over into the workplace the seamlessness means that viewers read Kenny's passivity as a positive character trait rather than as an exemplification of the ideal worker in a neoliberal regime. Kenny is clearly not a member of a union. He works extraordinarily long hours-there is an implication that this was a contributing factor to his marriage breakdown-and is willing to do extra work 
whenever his boss asks him. Here we can add Thomas Lemke's comments on the work experience in neoliberal philosophy:

As regards labour relations ... this means that work and leisure time are no longer inimical opposites, but tend to supplement each other ... Flexible working hours, self-determined work teams, performance stimuli, etc are no longer intended to transform the organization of production, but ... are aimed at the very relations between individuals and their labour. ${ }^{37}$

From the look of where he lives Kenny is paid very little and while he appears to be in charge of his workmates there seems to be no formal acknowledgement of his role. Unlike his aspirational brother, when Kenny is offered a promotion he turns it down. It appears that aspiration is linked with selfishness which is here marked negatively because the ideological thrust of the film is to legitimate Kenny's accepting personality. Kenny is the submissive Aussie battler in a neoliberal world.

One way the film produces Kenny as an Aussie battler is to make out the middle class to be unthinking and self-serving. Thus we have the university student working for Kenny who leaves rather than put his hand in shit to find a dropped ring, and also the girl who gets her ring back after Kenny retrieves it, whose thanks suggests that Kenny was simply doing his job. Then there are the drunken women at Flemington racecourse, one of whom pisses herself in front of Kenny while her friend falls over laughing into the mud and urine. All these images lead up to Kenny's declaration of class war when he starts filling with sewerage the car that has blocked-in his parked tanker.

The interaction between the classes is constructed as carnivalesque. In Rabelais and His World, Mikhail Bakhtin argued that, given the taken for granted hierarchical social order in the Middle Ages:

The suspension of all hierarchical precedence during carnival time was of particular significance ... all were considered equal during carnival. Here, in the town square, a special form of free and familiar contact reigned among people who were usually divided by the barriers of caste, property, profession, and age. ${ }^{38}$

Peter Stallybrass and Allon White rework this formulation, arguing that 'the idea of carnival as an analytic category can only be fruitful if it is displaced onto the broader concept of symbolic inversion and transgression'. 39 'Inversion', they explain elsewhere, 'addresses the social classification of values, distinctions and judgements, which underpin practical reason and systematically inverts the relations of subject and object, agent and instrument, husband and wife, old and young, animal and human, master and slave'. ${ }^{40}$ To this list of elements of what is known as 'the world turned upside down', we can add, thinking of Kenny, middle class and working class. Kenny, then, has a Rabelaisian quality to it which suggests that 
Kenny's legitimation as a salt-of-the-earth worker, a version of the Aussie battler stereotype, comes at the price of a fantastic social inversion. That is, in this comedic fantasy world, Kenny is constructed as the rational, humane person while the middle class are selfish, unthinking, pleasure-seeking and irresponsible. This is the source of the film's humour. Ideologically, then, the film is actually asserting the complete opposite. After the incident where Kenny fills the car with sewage, we do not see the police arrive; we do not see Kenny lose his job; we do not see him in court; we do not see him have to pay for the damage to the car. Kenny's attack on the middle class reads as a carnivalesque inversion of neoliberal class warfare that viewers know can only happen in fiction. The impact of making the film as a mockumetary is to use documentary techniques to give the film's inverted image of the neoliberal social order a greater vraisemblance-in the term used by Roland Barthes, what can be translated as real-seemingness. ${ }^{41}$

\section{- ViOLENCE, EXCLUSION AND JINDABYNE}

Which brings us to Jindabyne. As I have already remarked, there is no serial killer in Carver's original story, 'So Much Water So Close To Home', the first version of which was published in 1975. Rather, the murder of Susan Miller is constructed as an isolated incident and, by the story's end, the police have taken a man, 'a longhair', into custody for the crime-though some of the narrative's sense of ominousness comes from the implicit suggestion that they might have the wrong man. In Jindabyne the police come nowhere near catching Gregory, the serial killer. Within this narrative their presence is almost completely limited to expressing what we can now understand as traditional, moral outrage that the four men did not report finding the body immediately. The ineffectiveness of the police is linked to their positioning as representatives of the pre-neoliberal state.

In Carver's much earlier story Susan Miller is white. Here, then, because of her whiteness, race is not directly an issue. In this pre-neoliberal world, the story reads as focused on the moral concerns the importance of which can be taken for granted where, in Jindabyne, they have to be highlighted by the police. After all, in a neoliberal world where, to paraphrase Thatcher, there are only individuals and people must look to themselves first, why shouldn't these men do a bit of recreational fishing before reporting the body of a girl none of them know? In Jindabyne, Susan is Indigenous. Ray Lawrence has told how, 'Bea [Beatrix Christian, the screenwriter] said, "What if the murdered girl were Aboriginal?" and the story suddenly became much bigger and more important in the Australian context'. ${ }^{42}$ Lawrence does not explain what he thinks that importance is but Mireille Juchau argues that 'when the film broaches the huge and complicated matter of reconciliation, it falters, drawing a precarious bow from the collusion of the men (who lie to cover their negligence) to comment on Australia's failure to confront and make amends for the suffering of the Indigenous people'. ${ }^{43}$ 
Juchau is particularly critical of the scene where Claire and the other whites turn up uninvited at the Indigenous ceremony to mark Susan's passing. She writes, 'Something is badly wrong with this scene'. It is indeed. The problem is that the narrative drive of Gregory's murderous ways leads in a different ideological direction—as, as we have seen, does the narrative drive of the rampaging Burns gang in The Proposition. Gregory is not captured. The murder is not resolved. The wrong done to Susan and the Indigenous community is not righted by Australian law. Rather, as I have remarked, the final scene of the film finds Gregory back on his rocky outcrop surveilling the plain and the road which runs through it. He is still doing his job, patrolling the limits of white, settler Australia.

Elsewhere, I have written about Mick Taylor, the serial killer in Wolf Creek. ${ }^{44}$ I quoted Elliott Leyton who, in Compulsive Killers, suggests that the serial killer 'is in many senses an embodiment of the central themes in his civilization as well as a reflection of that civilization's critical tensions'. ${ }^{45}$ I argued that Taylor's murders of tourists can be read as an expression of the Australian government's murderous anxiety to protect Australia's borders at, seemingly, any cost. From this point of view it is significant that, as he is killing one of the English backpackers, Taylor tells her that he served in the Vietnam War. Taylor can be read as the individualised expression of the militarisation of neoliberal Australia's border.

I want to take this argument about Taylor and Gregory a step further and suggest that this murderous preoccupation with exclusion can be read in terms of the violence endemic in the neoliberal state. This is the violence that I have quoted Harvey earlier explaining as inherent in the neoliberal understanding of freedom. Lemke writes of neoliberalism that:

The strategy of rendering individual subjects 'responsible' ... entails shifting responsibility for social risks such as illness, unemployment, poverty, etc and for life in society into the domain for which the individual is responsible and transforming it into a problem of 'self-care'. ${ }^{46}$

If Taylor can be thought of as the ideological embodiment of the neoliberal militarisation of Australia's borders, the intent of which is a 'war' to exclude asylum seekers and refugees, then Gregory can be read similarly as patrolling the white, neoliberal Australian state, excluding the members of the disadvantaged Indigenous community who are identified as different and are seeking acceptance as a community. As I have argued, neoliberalism refuses to countenance claims to special treatment on the grounds of social disadvantage. People are welcomed within the state as individuals and excluded as members of communities. From a neoliberal perspective issues such as reconciliation and the attempts to get an apology for the treatment of the people who are now collectively described as belonging to the Stolen Generation, that is, those who were taken from their parents to be brought up in white-run institutions in order to speed Indigenous assimilation, simply reinforce Indigenous exclusion. 
In this sense Gregory makes clear the murderous exclusion within the white-dominated, neoliberal Australian state that is implicit in Wolf Creek where there are no Indigenous characters-where they are, if you like, always already absent.

In this context it is more understandable that Jindabyne should begin with a seemingly gratuitous shot of a barbed wire fence. In Australia since 2000 such fences are likely to connote the detention centres used to hold asylum seekers and those from whom citizenship has been withdrawn. ${ }^{47}$ They are markers of violent exclusion from the state. Gregory's sweeping of Indigenous people off the Jindabyne plain, the production, it would seem, of a literal terra nullius, connects with the violent history of the white settler genocide of Aborigines. At the same time, Gregory's serial killing can be understood in the terms of neoliberal exclusionary violence within the Australian state. In this way, Gregory's actions on the inner border of the Australian state equate with Mick Taylor's deadly protection of Australia's border from those who would enter from the outside. That barbed wire fence works, then, as a marker of this exclusionary structure.

Australia is increasingly a state founded on exclusion rather than inclusion where the hierarchical order is enforced by a violence that has become acceptable and naturalised since the setting aside of notions of the social contract. The state itself is organised according to assumptions about the transcendental value of the free market and, as a consequence, citizens are seen as competing possessive individuals rather than members of groups more or less socially advantaged and disadvantaged by their culturally ascribed attributes. These ideological elements that found the neoliberal understanding of social order are now themselves being naturalised in Australian cultural productions—such as the films that I have been discussing. One consequence is that Australian attitudes to minority and disadvantaged groups are becoming increasingly selfish, uninterested in the causes of disadvantage and celebrating individualistic policies such as assimilation over the group-based concerns of multiculturalism. Murderous Katrina and passive Kenny are role models for citizens of the new Australian neoliberal state. Mick Taylor and Gregory, serial killers, are the individualised ideological incarnations of the protectors of that murderous state.

JON STRATTON is Professor of Cultural Studies at Curtin University of Technology. He has published widely in cultural studies, popular music studies and Jewish cultural studies. His most recent books are Australian Rock: Essays on Popular Music (2007) and Jewish Identity in Western Pop Culture: The Holocaust and Trauma Through Modernity (2008). Jon is currently finalising a book on Jews, race and popular music which should be published late 2009.<J.Stratton@curtin.edu.au> 
1. Avril Curruthers, 'Jindabyne', In Film Australia, $<$ http://www.infilm.com.au/reviews/ jindabyne.htm>.

2. There is, of course, a long history of cultural film analysis in Australia. Perhaps most relevant to my arguments here are Graeme Turner's National Fictions: Literature, Film, and the Construction of Australian Narrative, Allen and Unwin, Sydney, 1986; Susan Dermody and Elizabeth Jacka's two volume The Screening of Australia, Currency Press, Sydney, 1987-88 and The Imaginary Industry: Australian Film in the Late '80s, Australian Film, Television and Radio School, Sydney, 1988; and Tom O'Regan's Australian National Cinema, Routledge, London, 1996.

3. Dennis Woodward, Australia Unsettled: The Legacy of 'Neoliberalism', Pearson Education Australia, Sydney, 2005, p. 33

4. This version of this notorious statement is taken from the Margaret Thatcher Foundation website at: <http://www.margaretthatcher.org/speeches/ displaydocument. asp?docid=106689>

5. Henry Giroux, 'Neoliberalism and the Demise of Democracy: Resurrecting Hope in Dark Times', Dissident Voice, 7 August 2004, $<$ http://www.dissidentvoice.org/Aug04/ Giroux0807.htm>

6. Thomas Hobbes, Leviathan, ed. C. B. MacPherson Penguin, London, 1968, p. 186

7. C. B. MacPherson, The Political Theory of Possessive Individualism: Hobbes to Locke, Oxford University Press, Oxford, 1962, p. 59

8. MacPherson, p. 70

9. Friedrich Hayek, The Constitution of Liberty, University of Chicago Press, Chicago, 1960, p. 11

10. David Harvey, A Brief History of Neoliberalism, Oxford University Press, Oxford, 2005, p. 7.

11. Isaiah Berlin, 'Two Concepts of Liberty', in David Miller (ed.), Liberty, Oxford University Press, Oxford, 1991, p. 34.

12. Noam Chomsky, 'Face to Face with a Polymath: Noam Chomsky Interviewed by Various Interviewers', Frontline, November 2001 $<$ http://www.chomsky.info/interviews/ 200111-.htm>.

13. Maria Giannacopoulos, 'Mabo, Tampa and the Non-Justiciability of Sovereignty', in Suvendrin Perera (ed.), Our Patch: Enacting Australian Sovereignty Post-2001, Network Books, Perth, WA 2006 , pp. $47-8$

14. Harvey, p. 37

15. John Howard quoted in Bob Briton, 'Howard Grabs New Police State Powers', The Guardian, (the weekly newspaper of the Communist Party of Australia), 17 August 2005, <http://www.cpa.org.au/garchve05/ 124lpolice. html>
16. Anthony Burke 'Security Politics and Us', in Perera (ed.), Our Patch, p. 198.

17. Suvendrini Perera 'Our Patch: Domains of Whiteness, Geographies of Lack and Australia's Racial Horizons in the War on Terror', in Perera (ed.), Our Patch, p. 131.

18. Philip French, 'The Proposition', The Observer, 12 March 2006, <http://film.guardian.co.uk News_Story/Critic_Review/Observer_Film_of_ the_week/0,,1728880,00.html>

19. See Jon Stratton, 'Borderline Anxieties: Whitening the Irish and Keeping Out Asylum Seekers', in Aileen Moreton-Robinson (ed.), Whitening Race: Essays in Social and Cultural Criticism, Aboriginal Studies Press, Canberra, 2004, pp. 222-38.

20. Will Wright, The Wild West: The Mythical Cowboy and Social Theory, Sage, London, 2001, p. 27.

21. Andrew Urban, 'Suburban Mayhem', Urban Cinefile, <http://www.urbancinefile.com.au/ home/view.asp?a=12354\&s=Reviews>

22. Aihwa Ong, Neoliberalism as Exception: Mutations in Citizenship and Sovereignty, Duke University Press, Durham, 2006, p. 15.

23. Ong, p. 15.

24. Stephen R. Stoer and António M. Magalhães, 'The Reconfiguration of the Modern Social Contract: New Forms of Citizenship and Education', European Educational Research Journal, vol. 1, no. 4, 2002, p. 701

25. Stoer and Magalhães 'The Reconfiguration of the Modern Social Contract, p. 702

26. Quoted here from the blog of John Quiggin, Professor of Economics at Queensland University: 'Hayek and Pinochet', John Quiggin: Commentary on Australian and World Events from a SocialDemocratic Perspective, 12 September 2002, $<$ http://johnquiggin.com/index.php/archives/ 2002/09/12/hayek-and-pinochet/>. Quiggin takes the quotation, in Spanish, from the Spanish newspaper, El Pais, 22 June 1999. The translation is his.

27. Avril Curruthers, 'Q and A with Ray Lawrence', In Film Australia <http://www.infilm.com.au/ features/raylawrence.htm>. It is worth considering the word 'foreignness' here. It suggests that, in Lawrence's thinking, those included in Australian society by way of multiculturalism remain different and more excluded than the 'non-foreign' Anglos.

28. Ricardo J. Gomez, 'Globalized Neoliberalism: Refutation and Debacle', <http://72.14.253.104/ search?q=cache:s2Mv9xxVAE8J:web.whittier.edu/ academic/facultymasters/PCCLAS/ DrGomezPCCLASlecture.pdf+\%22let+me+start+ with+my+own+translation $\% 22 \&$ hl=en\& $\& \mathrm{ct}=$ $\operatorname{clnk\& cd}=1>$.

29. Ong, p. 16. 
30. George Caffentzis, 'Acts of God and Enclosures in New Orleans', Mute: Culture and Politics After the Net, 24 May 2006, < http://www.metamute.org/ en/acts-of-god-and-enclosures-in-new-orleans>

31. David Theo Goldberg, 'Devastating Disasters: Race in the Shadow(s) of New Orleans', Du Bois Review: Social Science Research on Race, vol 3, no 1, 2006, p. 8

32. Caffentzis. Italics in original

33. Narda Gilmore, 'Calls for Army help in Wadeye', transcript, Lateline, 19 May 2006, ABC Television, <http://www.abc.net.au/lateline/content/2006/ sl643231.htm>

34. Michael Dillon, 'National Security and the Failed State in Remote Australia', Nautilus Institute at RMIT University, 25 January 2007, $<$ http://nautilus.rmit.edu.au/forumreports/070la-dillon.html\#n3>.

35. For a more sympathetic reading of The Castle's use of Mabo, see Felicity Collins and Therese Davis, Australian Cinema After Mabo, Cambridge University Press, Cambridge, 2004, pp. 116-23.

36. Christine Stapleton, The Amazing Adventures of the Ordinary Australian: Narratives of Class in Contemporary Australian Culture, $\mathrm{PhD}$ thesis, La Trobe University, Melbourne, 2004.

37. Thomas Lemke, "The Birth of Bio-Politics"Michel Foucault's Lecture at the Collège de France on Neo-Liberal Governmentality', Economy and Society, vol. 30, no. 2, 2001, pp. 202-3

38. Mikhail Bakhtin, Rabelais and His World, Indiana University Press, Bloomington, 1984, p. 10

39. Peter Stallybrass and Allon White, The Politics and Poetics of Transgression, Methuen, London, 1986, p. 18. Stallybrass and White's italics.

40. Stallybrass and White, p. 56

41. For a general discussion, see Jonathan Culler, Structuralist Poetics: Structuralism, Poetics and the Study of Literature, Routledge and Kegan Paul, London, 1975.

42. Lawrence, in Avril Curruthers, 'Q and A with Ray Lawrence'.

43. Mireille Juchau, 'Below the Surface', Realtime Arts, no. 76, December 2005 - Janurary 2006 $<$ http://www.realtimearts.net/article/76/8252>.

44. Jon Stratton 'Dying To Come To Australia', in Suvendrini Perera (ed.), Our Patch, pp. 167-96.

45. Elliott Leyton, Compulsive Killers: The Story of Modern Multiple Murder, Washington Mews Books, New York, 1986, p. 269

46. Lemke, p. 201.

47. On detention centres and violence, see Joseph Pugliese 'Penal Asylum: Refugees, Ethics, Hospitality', Borderlands e-journal, vol. 1, no. 1, 2002, <http://www.borderlandsejournal.adelaide. edu.au/vollnol_2002/pugliese.html>. 